UDC 339.564

JEL Classification: Q11; Q13; Q17

DOI: https://doi.org/10.32317/2221-1055.202009103

Mohammad Sadegh Ebrahimi

\title{
The comparative study of Iran's export of nuts and dried fruits with rival countries: USA, China and Turkey
}

\begin{abstract}
The purpose of the article was to investigate the status of Iran's export of nuts and dried fruits compared to those of competing countries: US, China and Turkey.

Research methods. The necessary data was collected from the faostat database for four countries (USA, China, Turkey and Iran). Also the data for production and export of nuts and dried fruits in Iran were also extracted from the Ministry of Agriculture and Statistics Center in Iran.

Research results. The most important of nuts and dried fruits in Iran include pistachio and raisin. Sustainable non-oil export revenues, especially revenues from export of nuts and dried fruits in addition to the continuation of sustainable production can be achive to agricultural development and economic development of the country. The results of this research showed that Iran has $20 \%$ of the market value of exported products for nuts and dried fruit. But in recent years have been able to rival countries with proper planning a significant share of the global market gain of nuts and dried fruits.

Scientific novelty. There is a significant competitor for Iran in the field of export of nuts and dried fruits with countries such as: USA, China and Turkey. Statistics and information provided shows that Iran, in order to maintain their competitiveness in the global market, should be have comprehensive properly planned.

Practical significance. One third non-oil export of Iran is dedicated to the export of nuts and dried fruits. Futurism can be very important for the sustainable export of these products in the form of scientific research. Tabl.: 3. Figs.: 11. Refs.: 20.

Keywords: export; dried fruit; nuts; Iran; rival countries.
\end{abstract}

Mohammad Sadegh Ebrahimi - assistant professor of Agricultural Development, Department of Rural Development, College of Agriculture, Isfahan University of Technology (IUT) (Isfahan, 84156-83111, Iran)

E-mail: Ebrahimi_ms@iut.ac.ir

ORCID iD https://orcid.org/0000-0003-3193-9726

Scientific problem. Export in all countries and in international trade is very important. The reason lies in the fact that no country can complete its own needs, produce and also if it is possible to produce all the goods and services required are not economical. Therefore, countries have a considerable amount of goods and services imported from other countries. On the other hand do require imports of foreign exchange and financial resources and therefore the country by producing and exporting goods in their economic advantage to providing the necessary financial resources. Thus, countries are not able to survive without export. Therefore, export promotion is an integral part of economic policy (Samaei, 2009). The results of the study show that with an increase of $1 \%$ in the growth of Export of goods and services to GDP growth rate will be

(C) Mohammad Sadegh Ebrahimi, 2020 added as much as 19 percent. Is because in most of the world, given the importance of the export sector and it is named as a driving force for other sectors. Emphasis on the development of non-oil Export as an important strategy, including methods of achieving sustained economic growth in Iran (Soltani, 2009). The import and export of agricultural sector is important as one of the most important indicators of food security in communities, especially in developing countries. According to the available information, from 2000 to 2015, the value of agricultural Export of Iran has increased $\$ 880$ million to nearly $\$ 5.5$ billion. But it was while imports agricultural products over the years, has increased from 2.6 billion dollars the amount to $\$ 9$ billion (Table 1). Over the past years, despite the ebbs and flows of Export and imports of many agricultural sector, there was always a constant principle in the export and import of 
agriculture. And it also increases the value of imports over Export and has been a negative trade balance gap in the agricultural sector. However, this in turn is very important. Reform of the status quo in general, can be examined in two strategy that included:

1. Increasing agricultural Export.
2. Revising methods to reduce imports of food and agricultural products.

Note the necessity of importance to the stability of agricultural Export and foreign exchange is concerned with earnings from Export of specific products such as nuts and dried fruit.

Table. 1. Ratio of Export to imports and trade balance of the agricultural sector during the years $2000-2015$

\begin{tabular}{|c|c|c|c|c|}
\hline Year & Export (Billion \$) & Import (Billion \$) & Trade balance & The ratio of export to import \\
\hline 2000 & 0.88 & 2.57 & -1.69 & $34.2 \%$ \\
\hline 2001 & 1.00 & 2.65 & -1.65 & $37.7 \%$ \\
\hline 2002 & 1.16 & 2.34 & -1.18 & $49.6 \%$ \\
\hline 2003 & 1.67 & 2.60 & -0.93 & $64.2 \%$ \\
\hline 2004 & 1.41 & 3.10 & -1.69 & $45.5 \%$ \\
\hline 2005 & 2.28 & 3.16 & -0.88 & $72.2 \%$ \\
\hline 2006 & 2.69 & 4.81 & -2.12 & $55.9 \%$ \\
\hline 2007 & 3.27 & 5.26 & -1.99 & $62.2 \%$ \\
\hline 2008 & 2.96 & 8.98 & -6.02 & $33 \%$ \\
\hline 2009 & 3.36 & 8.41 & -5.05 & $40 \%$ \\
\hline 2010 & 5.10 & 6.70 & -4.60 & $52.6 \%$ \\
\hline 2011 & 5.50 & 10.40 & -4.90 & $52.9 \%$ \\
\hline 2012 & 6.20 & 14.30 & -8.10 & $43.4 \%$ \\
\hline 2013 & 5.20 & 13.50 & -8.30 & $38.5 \%$ \\
\hline 2014 & 6.77 & 12.22 & -5.45 & $55.4 \%$ \\
\hline 2015 & 5.45 & 8.89 & -3.44 & $61.3 \%$ \\
\hline
\end{tabular}

Source: Iran Ministry of Jahad-e-Agriculture, adjustment and correction by researcher 2016.

\section{Nuts definition}

Defined, the culinary use of the word "nut" is rather varied. Botanically speaking, nuts are a composite of seed and dry fruit found inside of a hard outer shell. By definition, tree nuts are dry fruits with one seed in which the ovary wall becomes hard at maturity. The most popular edible tree nuts are almonds (Prunus amigdalis), hazelnuts (Corylus avellana), walnuts (Juglans regia), and pistachios (Pistachia vera) (Emilio, 2010).

\section{The importance of Iran's export of Nut}

According to information available to export of nuts in Iran's centuries-old history. In previous years generally pistachios, dates, raisins and almonds were considered as the most important export items nuts in Iran. Among Iran's agricultural export products, export products such as pistachio, raisins and dried apricots are the major share of the global export market (Amjadi et al 2010).

Analysis of recent research and publications. The value of agricultural Export in the development of this section of society is evident and clear so researchers have pointed out in their research. Salami and Pishbahar (2000), to study the comparative advantage and its changes during the 1989-1999 Iran paid for a group of horticultural crops. The results indicate that although calculated on the basis of criteria, Iran and intriguing clear comparative advantage in the production of the study products, But the economic behavior of producers and exporters in such a way that, producers failed to respond timely and appropriately to changes in the export structure show the region and the world (Jufrah and Farajollahi, 2013).

Farhadi and Mosadqi (2003) in their study concluded that agricultural export has a significant positive impact on the growth of the agricultural sector and also the instability of agricultural export earnings will be significantly negative impact on this sector (Farhadi and Mosadqi, 2003).

Azrinfar (2004) also studied the trends and factors affecting export of agricultural Export (pistachio, raisin, page, date) in Iran and the research result showed that apart from pistachio export, the export of other products has been fluctuating. The research result also showed that expressed inelastic the demand for Export of these products. It can be concluded that in stable condition, most cost through increased export earnings from the export of these products improved (Azrinfar, 2004). 
Khalid et al (2007) also study the relationship between economic growth, employment and Export in the agricultural sector in Iran. Their results showed that agricultural Export and a significant positive impact on employment and the development of the country (Khalid et al 2007). Rasekhi and Abedi (2011) studied the relationship between agricultural Export and the developing index and the result of this research showed that the agricultural Export had a positive effect to the developing index. Komijani and Haji (2002) result research and also the confirmed this.

The purpose of the article was to investigate the status of Iran's export of nuts and dried fruits compared to those of competing countries: US, China and Turkey.

Research results. According to available information, the country has a fundamental advantage in the production of dried fruits and nuts in the world. Iran's production of products such as: Pistachio and Dried-berries had the world's first rank and in products ranging from Plum (paper production) had the world's second rank and also in products such as walnuts, dates and almonds tree had the world's thrid rank. Although this ranks in different years due to fluctuations in production may be somewhat different. But in general, the evidence suggests the advantage of producing dried fruits and nuts in Iran and export statistics of such products in recent years, and particularly the sustainability of its export revenues is indicative of this advantage. As a result, production and export of dried fruits and nuts in Iran in are presented comparison with some other countries in the world shown in the Table 2.

Table 2. Production and export of dried fruits and nuts in Iran in are presented comparison with some other countries in the world

\begin{tabular}{|c|c|c|c|c|}
\hline Country & $\begin{array}{c}\text { Population } \\
\text { (million) }\end{array}$ & $\begin{array}{c}\text { Percent of employment } \\
\text { in agriculture }\end{array}$ & $\begin{array}{c}\text { Agriculture's } \\
\text { share of GDP }\end{array}$ & $\begin{array}{c}\text { Global rank in nuts production } \\
\text { USA }\end{array}$ \\
314 & 2 & 1.2 & $\begin{array}{c}\text { Almond trees (1), pistachio (2), } \\
\text { Walnut (2), grapes and raisins } \\
\text { (3) }\end{array}$ \\
\hline Turkey & 80 & 25 & 9.2 & $\begin{array}{c}\text { Hazelnut (1), apricot and tab } \\
\text { (1), figs (1), pistachio (3), Wal- } \\
\text { nut (4) }\end{array}$ \\
\hline Iran & 79 & 25 & 11.2 & $\begin{array}{c}\text { Pistachio (1), berry (1), dry apri- } \\
\text { cot (2), figs (2), raisins (3), Wal- } \\
\text { nut (3), date (2), almond (3) }\end{array}$ \\
\hline China & 1344 & 38 & 9.6 & $\begin{array}{c}\text { Grapes and raisins (1), peanuts } \\
(1), \text { Walnut (1) }\end{array}$ \\
\hline Spain & 47 & 4.2 & 3.3 & Almond (2) \\
\hline Italy & 61 & 4.2 & 1.9 & $\begin{array}{c}\text { Hazelnut (2), grapes and raisins } \\
\text { (2), dry apricots (3) }\end{array}$ \\
\hline Chile & 17 & 13.2 & 5.1 & Walnut (3) \\
\hline Egypt & 84 & 32 & 14.4 & Date (1), figs (2), \\
\hline
\end{tabular}

Source: FAO, 2015, adjustment and correction by researcher 2016.

Due to favorable climate of the Iran in the production of nuts, the country with having the production advantage of this product. So that as one of the largest producer and exporters of dried fruits and nuts in the world. Although the production of nuts, is faced with serious rivals. The most important competitor countries included: USA, Turkey and China.

Iran's export of Nuts

In 2011, Iran's most important export nuts based on their value include: pistachio(1.1billion \$), raisins (272 million \$), hazelnut (50 thousand \$), walnut (5 million \$), figs (21 million \$), almond (19 million \$) and dry apricots (2 million $\$$ ) respectively (Figure 1 ). It seems that the aggregate number of pistachios, raisins, dates and other dried fruits and nuts can be concluded that approximately two billion dollars worth of non-oil export of Iran and about one third of Iranian agricultural export is expected to the export of dried fruits and nuts. Then, this paper discusses to evaluate the production and export of Iran nuts and compared with rival three countries (USA, Turkey and China). 


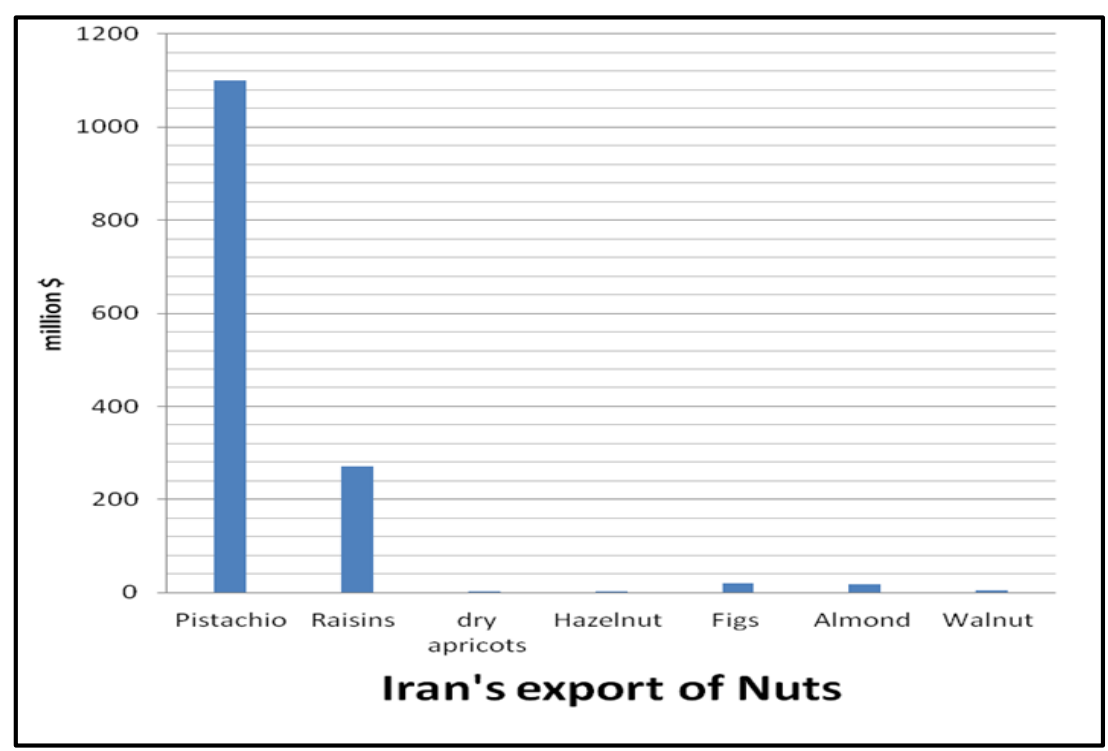

Figure 1. Iran's most important export nuts, 2011

Source: FAO, 2015, adjustment and correction by researcher 2016.

Iranian pistachio Export compared with competitor countries

At 2011, Iran exported 130 thousand tons of pistachio revenue of 1.1 billion $\$$ had the first rank in the world. In 2011, USA also exported the pistachio 105 thousand tons with a value of approximately 674 million $\$$ and also Turkey export the pistachio 12 thousand tons with a value of approximately 23 million $\$$ and China export the pistachio 5 thousand tons with a value of approximately 11 million $\$$ (Figure 2).

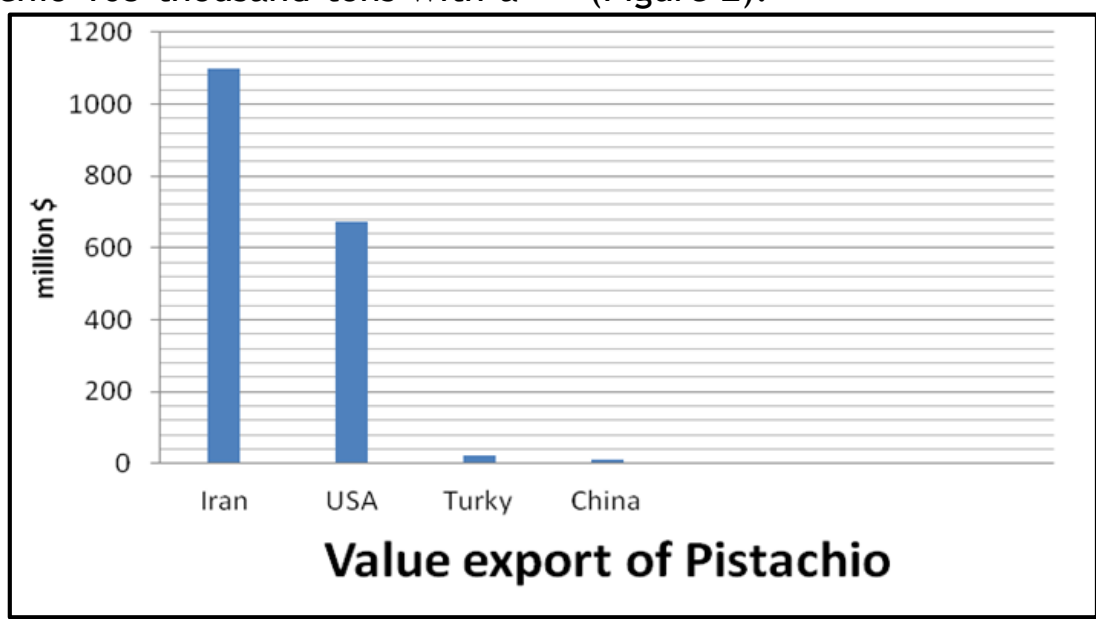

Figure 2. Value export of Pistachio, 2011

Source: FAO, 2015, adjustment and correction by researcher 2016 .

It seems that the strongest challenger to Iranian pistachio Export, is the USA and this country is the second largest producer of pis- tachios in the world. The pistachio production in Iran and the United States during the years 2000-2014 was on the Table 3, Figure 3.

Table 3. Pistachio production in Iran and the United States during the years 2000-2014

\begin{tabular}{|c|c|c|c|}
\hline Year & $\begin{array}{c}\text { Iranian pistachio production } \\
\text { (thousand tons) }\end{array}$ & $\begin{array}{c}\text { USA pistachio production } \\
\text { (thousand tons) }\end{array}$ & $\begin{array}{c}\text { Production ratio of USA } \\
\text { to Iran (percent) }\end{array}$ \\
\hline 2000 & 188 & 89 & 47 \\
\hline 2001 & 161 & 85 & 53 \\
\hline 2002 & 256 & 137 & 54 \\
\hline 2003 & 173 & 54 & 31 \\
\hline 2004 & 134 & 157 & 117 \\
\hline 2005 & 176 & 128 & 73 \\
\hline 2006 & 211 & 108 & 51 \\
\hline
\end{tabular}


Continued table 3

\begin{tabular}{|c|c|c|c|}
\hline 2007 & 267 & 189 & 71 \\
\hline 2008 & 90 & 126 & 140 \\
\hline 2009 & 184 & 161 & 88 \\
\hline 2010 & 216 & 237 & 110 \\
\hline 2011 & 157 & 203 & 129 \\
\hline 2012 & 183 & 252 & 138 \\
\hline 2013 & 170 & 218 & 128 \\
\hline 2014 & 230 & 233 & 101 \\
\hline
\end{tabular}

Source: US Administrative Committee for Pistachios, 2016.

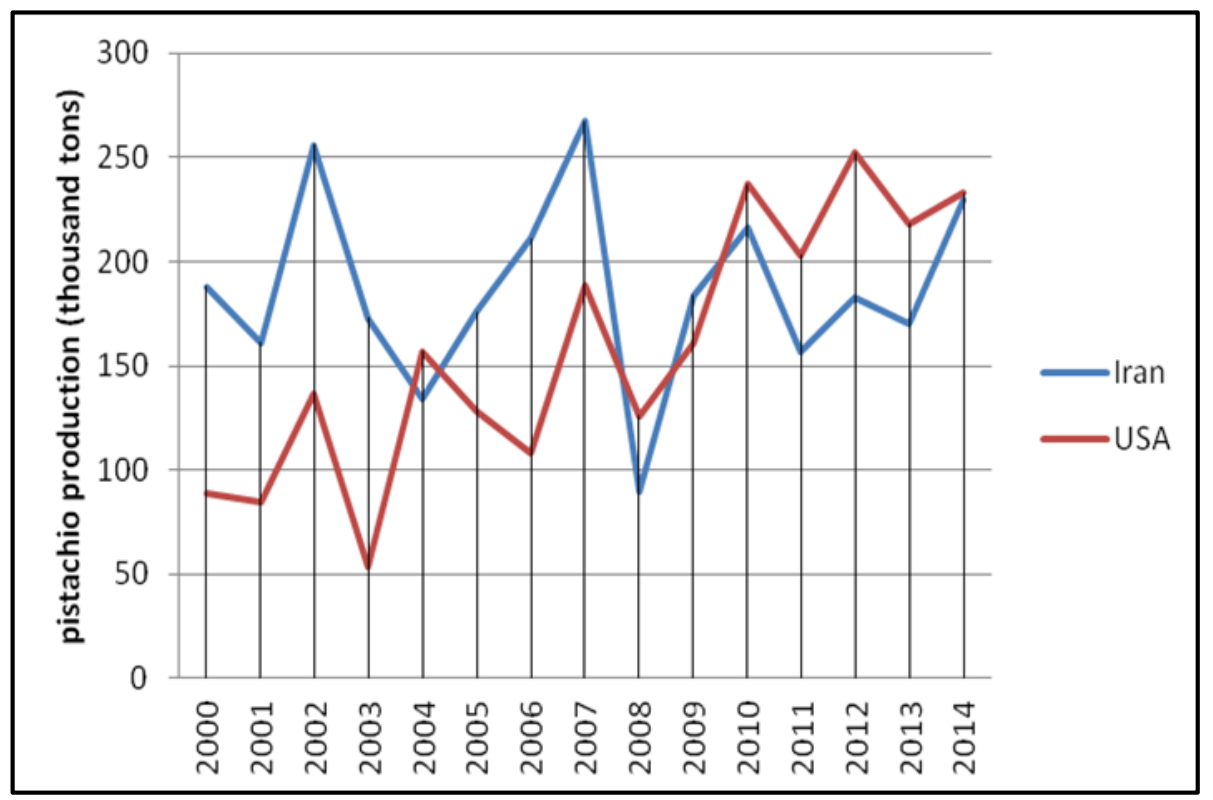

Figure 3. Volume production of Pistachio Iran and the United States during 2000-2014 Source: FAO, 2015, adjustment and correction by researcher 2016.

Iranian raisin Export compared with competitor countries

According to FAO (2011) the most important exporting raisin countries in the world included: Turkey, the United States and Iran. In 2011, Turkey exported 214 thousand tons of raisin revenue of 506 million $\$$ had the first

rank in the world. In 2011, USA also exported the raisin 149 thousand tons with a value of approximately 403 million $\$$ and also Iran export the raisin 113 thousand tons with a value of approximately 272 million $\$$ and China export the raisin 48 thousand tons with a value of approximately 103 million \$ (Figure 4).

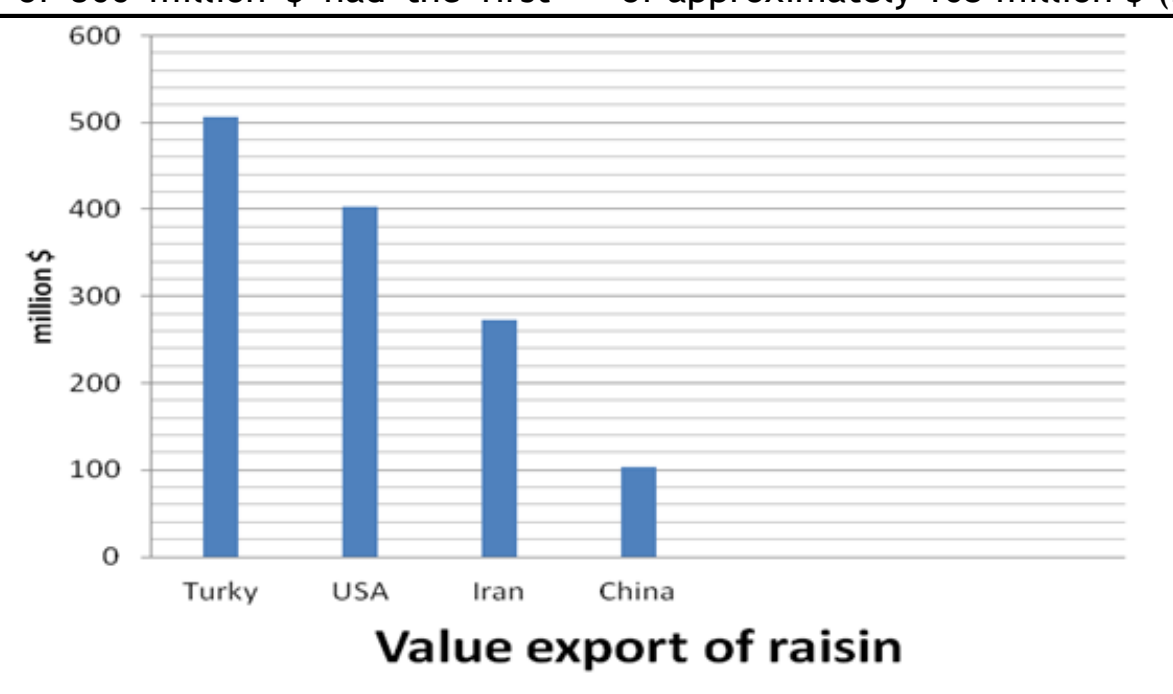

Figure 4. Value export of raisin, 2011

Source: FAO, 2015, adjustment and correction by researcher 2016. 
Iranian almond Export compared with competitor countries

According to FAO (2011) the most important exporting almond countries in the world included: the United States, Spain, Italy and China. In 2011, USA exported 450 thousand tons of almond revenue of 2.1 billion $\$$ had the first rank in the world. In 2011, China also exported the almond 24 thousand tons with a value of approximately 92 million $\$$ and also Turky export the almond 6 thousand tons with a value of approximately 48 million \$ and Iran export the almond 1.3 thousand tons with a value of approximately 19 million \$ (Figure 5).

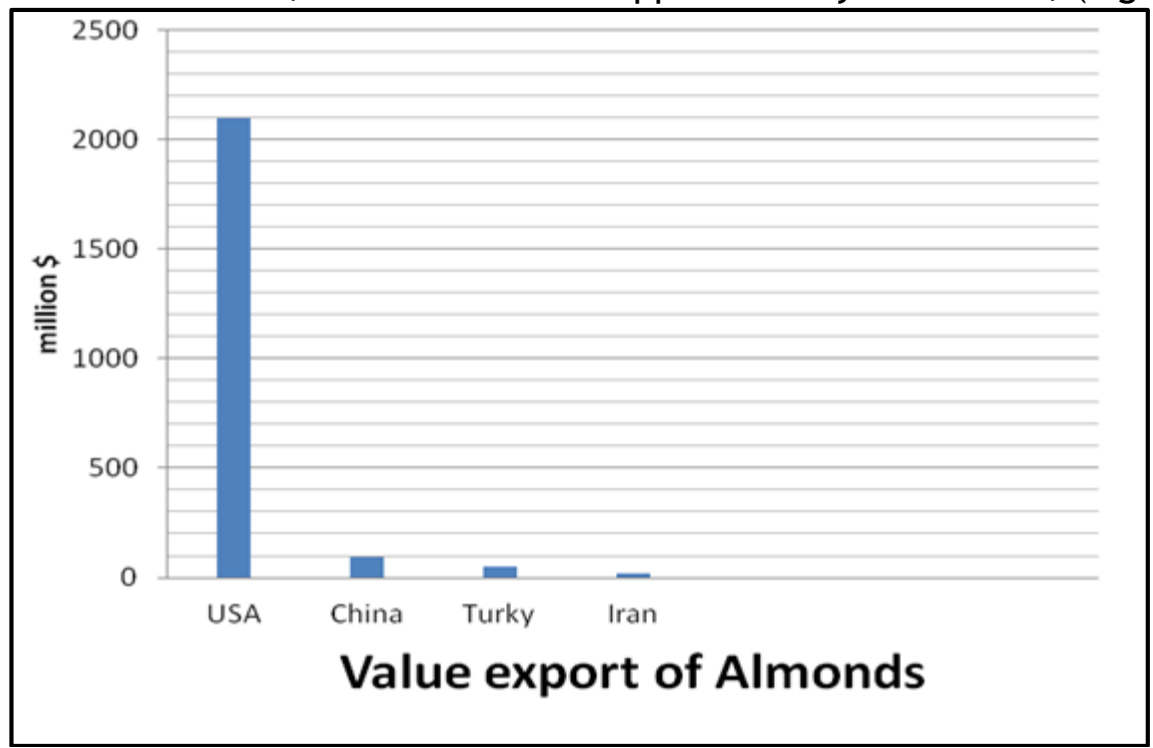

Figure 5. Value export of almond, 2011

Source: FAO, 2015, adjustment and correction by researcher 2016.

Iranian walnut Export compared with competitor countries

According to FAO (2011) the most important exporting walnut countries in the world included: the United States, Mexico and Chile. In 2011, USA exported 81 thousand tons of walnut revenue of 617 million $\$$ had the first rank in the world. In 2011, China also exported the walnut 7 thousand tons with a value of approximately 47 million $\$$ and also Turkey export the walnut 3.7 thousand tons with a value of approximately 36 million $\$$ and Iran export the walnut 1.5 thousand tons with a value of approximately 5 million $\$$ (Figure 6).

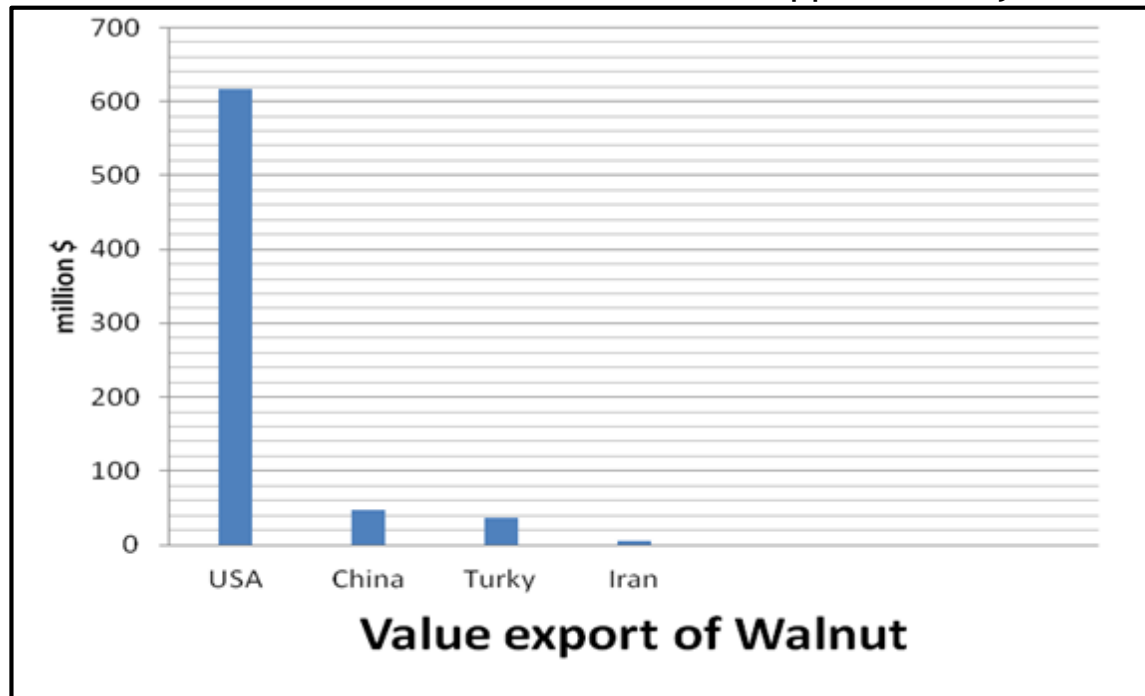

Figure 6. Value export of walnut, 2011

Source: FAO, 2015, adjustment and correction by researcher 2016.

Iranian hazelnut Export compared with competitor countries
According to FAO (2011) the most important exporting hazelnut countries in the world included: Turkey, Italy, Spain and USA. 
Turkey is the first world hazelnut producer and exporter. In addition, it covers approximately 70 percent and 82 percent of the world's production and Export respectively. Turkey exported the hazelnut is approximate- ly 1 billion $\$$ and also USA export the hazelnut 7 million $\$$ and china export approximately 1 million $\$$ and also Iran hazelnut Export are 0.05 million $\$$ (Figure 7).

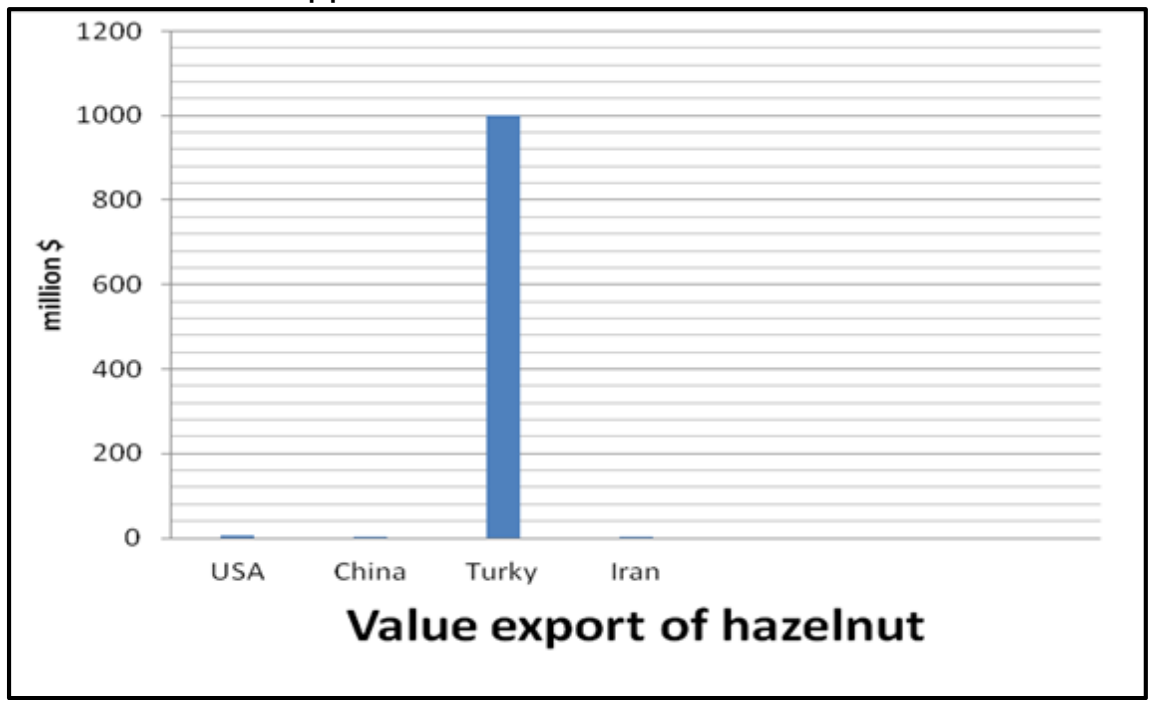

Figure 7. Value export of hazelnut, 2011

Source: FAO, 2015, adjustment and correction by researcher 2016.

Iranian fig Export compared with competitor countries

According to FAO (2011) the most important exporting fig countries in the world included: Turkey, Egypt, Aljazaier and Iran. Turkey is the first world fig producer and exporter. In 2011, Turkey exported 45 thousand tons of fig revenue of 151 million $\$$ had the first rank in the world. In 2011, USA also exported the fig 5.4 thousand tons with a value of approximately 21 million $\$$ and also Iran export the fig 5 thousand tons with a value of approximately 19 million \$ and China export the fig 0.5 thousand tons with a value of approximately 1.5 million $\$$ (Figure 8).

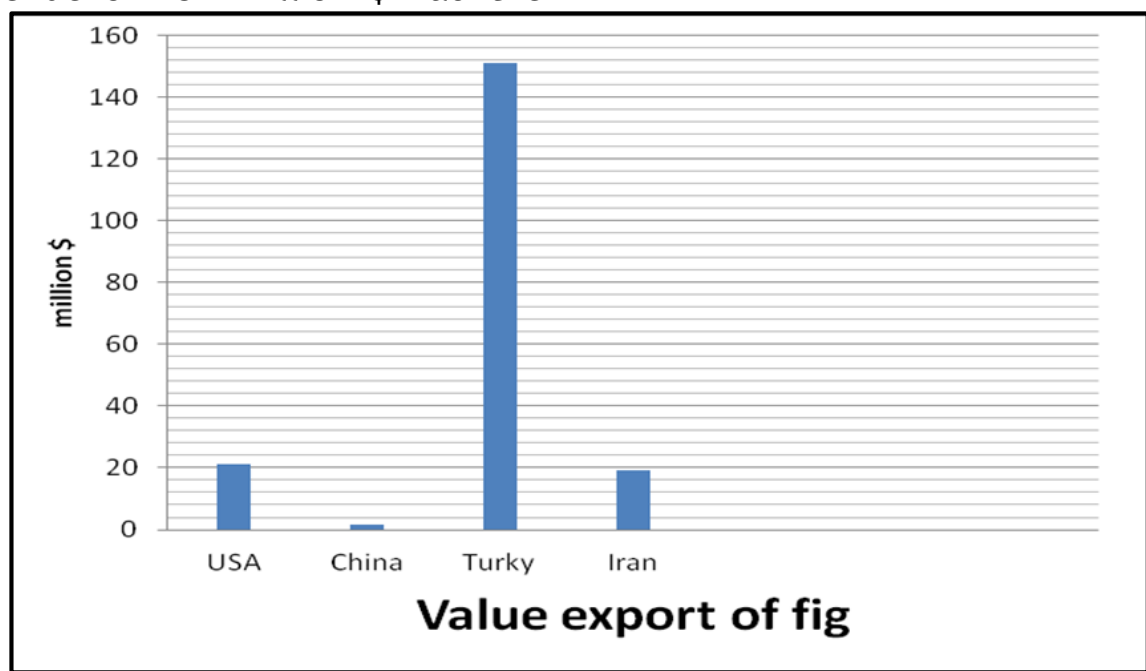

Figure 8. Value export of fig, 2011

Source: FAO, 2015, adjustment and correction by researcher 2016.

Iranian dry apricots Export compared with competitor countries

According to FAO (2011) the most important exporting dry apricots countries in the world included: Turkey, Germany and Afghanestan. Turkey is the first world dry apri- cots producer and exporter. In 2011, Turkey exported 90 thousand tons of dry apricots revenue of 361 million $\$$ had the first rank in the world. In 2011, USA also exported the dried apricots 1.7 thousand tons with a value of approximately 7 million $\$$ and also Iran ex- 
port the dried apricots 0.8 thousand tons with a value of approximately 2 million $\$$ and China export the dried apricots 0.5 thousand tons with a value of approximately 1.8 million $\$$ (Figure 9).

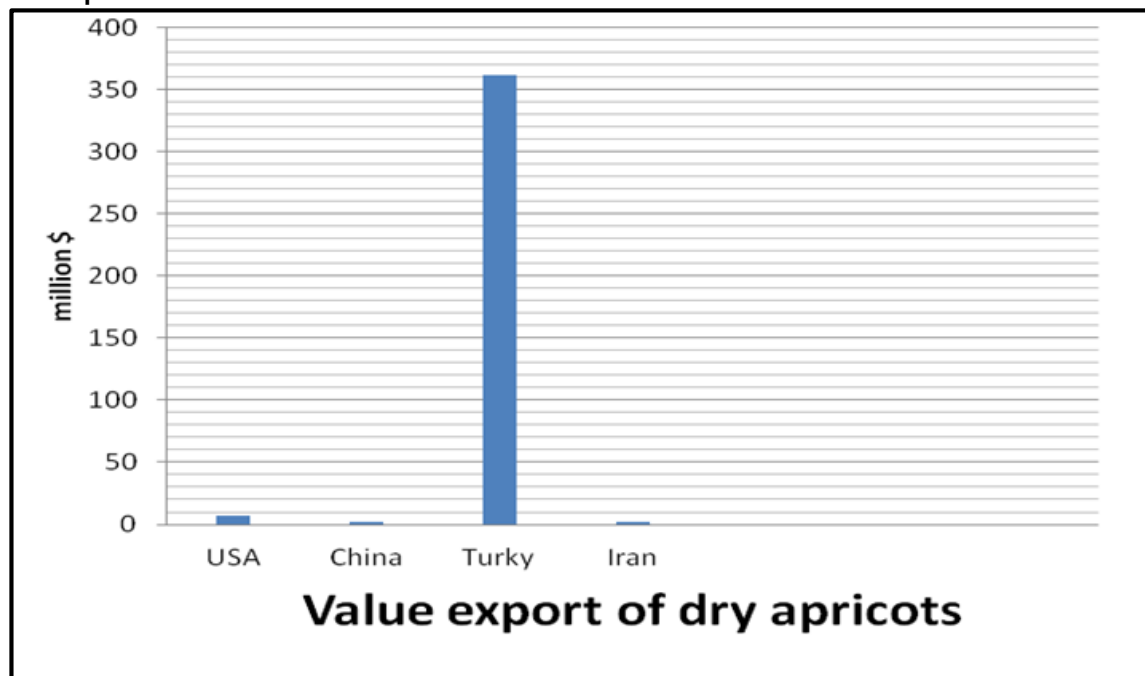

Figure 9. Value export of dry apricots, 2011

Source: FAO, 2015, adjustment and correction by researcher 2016.

Conclusions. Global market demand for dried fruits and nuts is a thriving market. As for the study of dried fruits and nuts (pistachio, raisins, figs, almonds, walnuts, hazelnuts, dried apricots) can generally demand a market valued at $\$ 10$ billion annually. In this global market, the USA, Iran, Turkey and China have the eighty percent of the world's supply of these products and consequently the value of its income in the world. Iran has the 20 percent of the value of Export of these products to the global market (Figure 10).

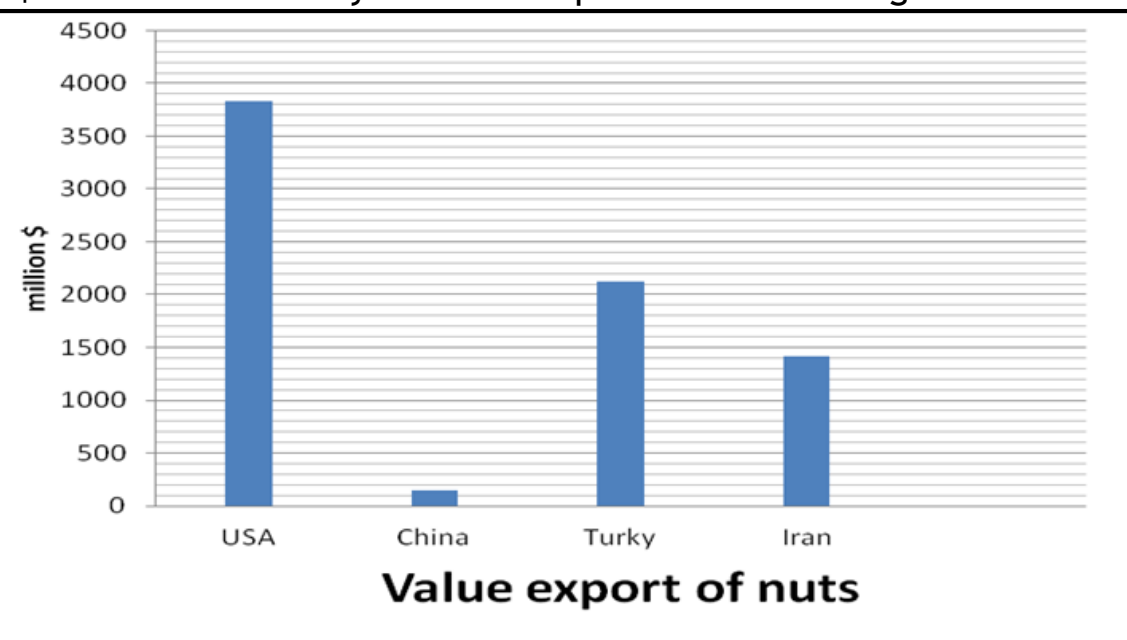

Figure 10. Value export of nuts

(pistachio, raisins, figs, almonds, walnuts, hazelnuts, dried apricots), 2011

Source: FAO, 2015, adjustment and correction by researcher 2016.

The global market for dried fruits and nuts with demand growth close to $3 \%$ during the past years. The statical data also identified during the study period Iran export income of these nuts was decreased nearly 15 per cent, while that of rival countries were increased their export income: China 45\%, Turkey 13\% United States 3 Percent (Figure 11). 


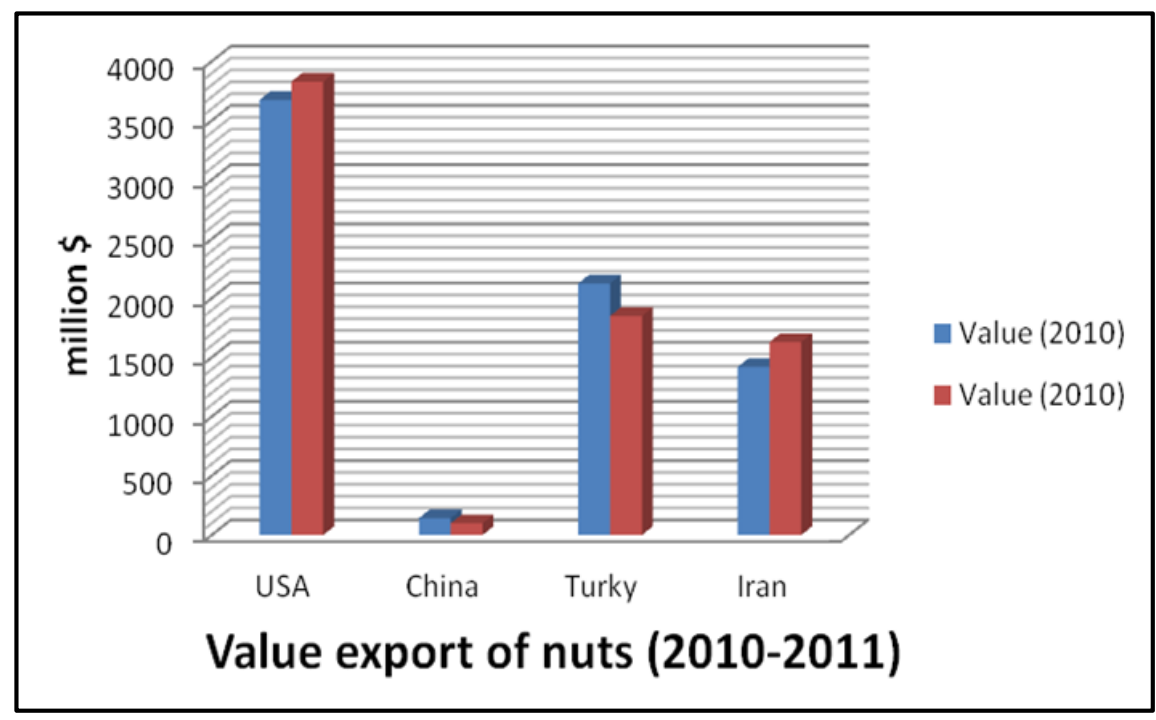

Figure 11. Value export of nuts, 2010-2011

Source: FAO, 2015, adjustment and correction by researcher 2016.

In the case of pistachios a serious competitor and always there is that the USA state is based on information provided shows that although production between Iran and the United States over the past 15 years has waned, but that seems to be the USA export of pistachio during the years from about 50 percent of Iran's Export have increased to near 100\%. In addition, China and Turkey are also planning to produce not only have its domestic market (close to $\$ 750$ million) from the share of export of Iranian pistachios outside are also able to close to $\$ 35$ million from the international market this product in Iranian pistachio. These statistics, are mentioned need to keep a regular schedule, in order to maintain domestic production and international market these specific products.

The export market value of raisins, four mentioned countries, is nearly $\$ 3.1$ billion annually, that had nearly 12 percent annual growth during 2010 and 2011, as Iran has not only not increased but also lost the 15 per cent of the international markets of raisin export. But the rival countries obtain this share of international market especially China. So that although Iran was faced with the loss of 50 million dollar international rains export, but to the rival countries obtain this share:Turkey $\$ 80$ million, US $\$ 70$ million and China 30 million US dollars). USA export of the almond is nearly 2.2 billion $\$$ a year (more than the total value of Iran Export nuts). During the study years, the value almond Export growth in Turkey and China was 40 and 30 percent respectively. It is obvious that the USA had increased your income from export earnings from selling walnuts amount 150 million $\$$ during the past year. It should be noted that Turkey be produced with less than a third of Iran capacity to walnuts produce, has obtained the five per cent the world's export market value. The value of Export of hazelnuts in the world was increased during the study period, 17 percent. All this added value has been provided to Turkey, this country more than one billion dollar in export income from sale hazelnuts in the world. Turkey has managed with proper planning nearly 99 percent of the world market for this product. Iran has suitable climate to growth the hazelnuts and increased the productivity both qualitatively and quantitatively appropriate to be planning, logical, principled and sustained in this field can also diversify the export of nuts to secure the growth of export income in the agricultural sector and thus the prosperity and development, and economic.

The value of Export of dried fig in the world nearly 350 millions of dollar annually. Nearly $60 \%$ of this market is in the hands of Turkey. Iran's export potential in this market is less than 15 percent. Since Iran is the world's fourth largest producer of figs in the word, therefore, achieved a share of at least 25 percent is not out of reach. More attention to improvement of processing and conversion processes of fresh fig and convert to dried fruit, is necessary, especially, develop the export of dried figs in Iran is important factors to the development of nuts export. Although Iran has capacity the second biggest producer of apricots in the world, but cannot obtain the logical share of this produce export 
in the world. Turkey had been acquired nearly 400 million $\$$ income from this product, but Iran had been acquired nearly 2 million $\$$ per year. Statistics and information provided shows that Iran, in order to maintain their competitiveness in the global market, should be have comprehensive properly planned. This

\section{Referances}

1. Amjadi A.,. Mohammad-Zadeh R., Barikani A. Iran's pistachio and date specified target markets using the model of export demand and screening methods. Iranian Economics and Development journal. 2010. № 6(70). P. 193-220.

2. Azarinfar $Y$. Considering the request for the export of some agricultural products exported from Iran. A Thesis for $a$ degree of Master of Science in Agricultural Economics. Faculty of Agriculture. Shiraz University. Iran. 2004.

3. Ebrahimi Mohammad Sadegh, Kalantri Khalil, Asadi Ali, Mohammadi Davoud. The comparison of inputs consumption sustainability in traditional and developed paddy fields in Iran. International Journal of Agriculture and Forestry. 2012. № 2(3). P. 84-87.

4. Emilio $R$. Health benefits of nut consumption. Nutrients. 2010. № 2(7). P. 652-682.

5. Farhadi A., Mosadqi R. Boost Export and economic growth. The fourth Conference of Agricultural Economics, Iran. Tehran. 2003.

6. FAO. Agriculture: towards 2015/2030. Technical interim report. Rome. FAO, 2000.

7. FAO. The state of food insecurity in the world. Rom FAO, 2001.

8. FAO. The initiative to review and update national agricultural, rural development and food security strategies and policies. Second draft. July, 2003.

9. FAO. Food Security. The State of Food Security in the World, 2006.

10. FAO, 2016. URL : www. FAO. org

11. Jufrah M., Farajollahi G. Analysis of factors affecting the export of pistachio in Iran. Iranian Journal of Economic Sciences. 2013. № 6. P. 67-82.

12. Khalid K., Ardestani M., Tousi M. Examine the relationship between economic growth, employment and Export in the agricultural sector of Iran - with an emphasis on currency and trade policies, the Sixth Conference of Agricultural Economics, Iran, Mashhad. 2007.

13. Komijani A., Haji GH. The role of Export in productivity and economic growth: empirical evidence from Iran. Iranian Journal of Research in economic growth and development. 2002. № 2(7). P. 11-34.

14. Ministry of Jahad-e-Agriculture. Iran. Ratio of Export to imports and trade balance of the agricultural sector in Iran, 2015.

15. Rasekhi A., Abedi F. Study on agricultural Export and economic growth and development years (1976-2009). Iranian Journal of researches economic growth and development. 2011. № 1(2). P. 95-111.

16. Samaei SR. Explaining financing instruments and their role in the development of the country's Export. Thesis Master of Public Administration. Faculty of Management and Economics. Tarbiat Modarres University. Iran, 2009.

17. Soltani Elizabeth. The role of productivity in economic growth and development of non-oil Export (Case study: Fars). Economic Journal - monthly issues and economic policies. 2009. № 95-96. P. 1-29.

18. Tzouvelekas V., Pantzios C.J., Fotopoulos C. Technical efficiency of alternative farming systems: the case of Greek organic and conventional olive-growing farms. Food Policy. 2001. Vol. 26. № 6. P. 549-569.

19. UNDP, 2012. URL : WWW. UNDP.org

20. US Administrative Committee for Pistachios, 2017. URL : http://www.acpistachios. org/statistics.shtml. program, to be considered and maintained the strengths and weaknesses of nuts production and export of Iranian nuts. In this regard, the observation and study of the production and export of dried fruits and nuts by rival countries is very important.

\section{Referances}

1. Amjadi, A., Mohammad-Zadeh, R. and Barikani, A. (2010). Iran's pistachio and date specified target markets using the model of export demand and screening methods. Iranian Economics and Development journal, 6(70), pp. 193-220 [In English].

2. Azarinfar, Y. (2004) Considering the request for the export of some agricultural products exported from Iran. A Thesis for a degree of Master of Science in Agricultural Economics. Faculty of Agriculture. Shiraz University. Iran [In English].

3. Ebrahimi Mohammad Sadegh, Kalantri Khalil, Asadi Ali and Mohammadi Davoud. (2012). The comparison of inputs consumption sustainability in traditional and developed paddy fields in Iran. International Journal of Agriculture and Forestry 2012, 2(3), pp. 84-87 [In English].

4. Emilio, R. (2010). Health benefits of nut consumption. Nutrients. 2(7), pp. 652-682 [In English]

5. Farhadi, A. \& Mosadqi, R. (2003). Boost Export and economic growth. The fourth Conference of Agricultural Economics, Iran. Tehran. 2003 [In English].

6. FAO. (2000). Agriculture: towards 2015/2030. Technical interim report. Rome. FAO [In English].

7. FAO. (2001). The state of food insecurity in the world. Rom FAO [In English].

8. FAO. (2003). The initiative to review and update national agricultural, rural development and food security strategies and policies. Second draft. July, 2003 [In English].

9. FAO. (2006). Food Security. The State of Food Security in the World [In English].

10. FAO. (2016). Www. FAO.org [In English].

11. Jufrah, M. and Farajollahi, G. (2013). Analysis of factors affecting the export of pistachio in Iran. Iranian Journal of Economic Sciences, 6, pp. 67-82 [In English].

12. Khalid, K. Ardestani, M. and Tousi, M. (2007). Examine the relationship between economic growth, employment and Export in the agricultural sector of Iran - with an emphasis on currency and trade policies, the Sixth Conference of Agricultural Economics, Iran, Mashhad. 2007 [In English].

13. Komijani, A. and Haji, GH. (2002). The role of Export in productivity and economic growth: empirical evidence from Iran. Iranian Journal of Research in economic growth and development, 2(7), pp. 11-34 [In English]

14. Ministry of Jahad-e-Agriculture. Iran (2015). Ratio of Export to imports and trade balance of the agricultural sector in Iran [In English].

15. Rasekhi, A. and Abedi, F. (2011). Study on agricultural Export and economic growth and development years (19762009). Iranian Journal of researches economic growth and development, 1(2), pp. 95-111 [In English].

16. Samaei, SR. (2009). Explaining financing instruments and their role in the development of the country's Export. Thesis Master of Public Administration. Faculty of Management and Economics. Tarbiat Modarres University. Iran [In English].

17. Soltani, Elizabeth (2009). The role of productivity in economic growth and development of non-oil Export (Case study: Fars). Economic Journal - monthly issues and economic policies, No. 95 and 96, pp. 1-29 [In English].

18. Tzouvelekas, V. Pantzios, C.J. Fotopoulos, C. (2001). Technical efficiency of alternative farming systems: the case of Greek organic and conventional olive-growing farms. Food Policy, vol. 26, No. 6, pp. 549-569 [In English]

19. UNDP. (2012). WWW. UNDP.org [In English].

20. US Administrative Committee for Pistachios, (2017). Retrieved from: http://www.acpistachios. org/statistics.shtml [In English]. 
Мохаммад Садег Ебрагімі. Порівняльне дослідження експорту з Ірану горіхів та сухофруктів щодо країнконкурентів: США, Китаю та Туреччини

Meта статmі - проаналізувати стан експорту Іраном горіхів і сухофруктів порівняно з країнами-конкурентами: США, Китай та Туреччина.

Методика дослідження. Необхідні матеріали було взято з бази даних ФАО для чотирьох країн (США, Китай, Туреччина та Іран). Також дані щодо виробництва й експорту горіхів і сухофруктів в Ірані отримано від Міністерства сільського господарства та статистичного центру Ірану.

Результати дослідження. Найважливіші різновиди горіхів і сухофруктів в Ірані це фісташки та родзинки. Стійкі ненафтові доходи від експорту, особливо доходи від експорту горіхів та сухофруктів у продовження сталого виробництва, можуть сприяти розвитку сільського господарства та економічному розвитку країни. Як показали результати проведеного дослідження, Іран має 20\% ринкової вартості експортованої продукції горіхів і сухофруктів. Протее за останні роки країнам-конкурентам з належним плануванням вдалося захопити значну частку світового ринку горіхів $i$ сухофруктів.

Елементи наукової новизни. Іран має потужних конкурентів в галузі експорту горіхів і сухофруктів, серед яких такі країни, як США, Китай та Туреччина. Наведені статистичні дані та інформація засвідчили, що для підтримки власної конкурентоспроможності на світовому ринку Іран повинен запровадити всебічне належне планування.

Практична значущість. Третина іранського ненафтового експорту припадає на горіхи та сухофрукти. Футуризм може бути дуже важливим для сталого експорту цієї продукції у формі наукових досліджень. Табл.: 3. Puс.: 11. Бібліогр.: 20.

Ключові слова: експорт; сухофрукти; горіхи; Іран; країни-конкуренти.

Мохаммад Садег Ебрагімі - доцент кафедри розвитку сільського господарства, Департамент розвитку сільських територій, Сільськогосподарський коледж Ісфаханського технологічного університету (Ісфахан, 84156-83111, Іран)

E-mail: Ebrahimi_ms@iut.ac.ir

ORCID iD https://orcid.org/0000-0003-3193-9726

Мохаммад Садег Эбрагими. Сравнительное исследование экспорта с Ирана орехов и сухофруктов относительно стран-конкурентов: США, Китая и Турции

Цель статьи - исследовать состояние экспорта Ираном орехов и сухофруктов по сравнению со странамиконкурентами: США, Китай и Турция.

Методика исследования. Необходимые материалы были взяты из базы данных ФАО для четырех стран (США, Китай, Турция и Иран). Также данные по производству и экспорту орехов и сухофруктов в Иране получены от Министерства сельского хозяйства и статистического чентра Ирана.

Результаты исследования. Важнейшие разновидности орехов и сухофруктов в Иране это фисташки и изюм. Устойчивые ненефтяные доходы от экспорта, особенно доходы от экспорта орехов и сухофруктов в продолжение устойчивого производства, могут способствовать развитию сельского хозяйства и экономическому развитию страны. Как показали результаты исследования, Иран имеет 20\% рыночной стоимости экспортируемой продукции орехов и сухофруктов. Но за последние годы странам-конкурентам с должным планированием удалось захватить значительную долю мирового рынка орехов и сухофруктов.

Элементы научной новизны. Иран имеет мощных конкурентов в отрасли экспорта орехов и сухофруктов, среди которых такие страны, как США, Китай и Турция. Приведенные статистические данные и информация засвидетельствовали, что для поддержания собственной конкурентоспособности на мировом рынке Иран должен ввести всестороннее надлежащее планирование.

Практическая значимость. Треть иранского ненефтяного экспорта приходится на орехи и сухофрукты. Футуризм может быть очень важным для устойчивого экспорта этой продукции в форме научных исследований. Табл.: 3. Илл.: 11. Библиогр.: 20

Ключевые слова: экспорт; сухофрукты; орехи; Иран; страны-конкуренты.

Мохаммад Садег Эбрагими - доцент кафедры развития сельского хозяйства, Департамент развития сельских территорий, Сельскохозяйственный колледж Исфаханского технологического университета (Исфахан, 8415683111, Иран)

E-mail: Ebrahimi_ms@iut.ac.ir

ORCID iD https://orcid.org/0000-0003-3193-9726

The article has been received 07.09.2020

Revision: 14.09.2020

Бібліографічний опис для цитування:

Mohammad Sadegh Ebrahimi. The comparative study of Iran's export of nuts and dried fruits with rival countries: USA, China and Turkey. Економіка АПК. 2020. № 9. С. 103 - 113. https://doi.org/10.32317/2221-1055.202009103

Mohammad Sadegh Ebrahimi (2020). The comparative study of Iran's export of nuts and dried fruits with rival countries: USA, China and Turkey. Ekonomika APK, 9, pp. 103 - 113 [In English] https://doi.org/10.32317/2221-1055.202009103 